\title{
METHODOLOGIC DIRECTIONS IN CRIMINALISTIC RESEARCH FOR THE OFFENCE OF TRAFFICKING AND ILLICIT DRUG CONSUMPTION
}

\section{P-D. FERARIU, V. AVRĂMESCU}

\author{
Petronela-Diana FERARIU \\ Legal Adviser, Company EuroAsia of Iași, România, \\ diana.ferariu@gmail.com

\section{Valentina AVRĂMESCU} \\ "Dimitrie Cantemir" University of București, Faculty of Law, România, \\ valentina.avramescu@gmail.com
}

\begin{abstract}
:
The criminal activity of trafficking and illicit drug use is developing rapidly, new psychoactive substances are emerging at a rapid pace and represent a major threat to the health and safety of individuals. The actual crime in the case of trafficking and illicit drug use offence must be determined in terms of size the participants and causes. The distinction between real crime and apparent crime is defined as the "dark number or hidden figure of crime" (Rădulescu S., 1999, 189) The use of this concept is specifically used in the case of the number of crimes committed and remained unknown to the society, for various reasons. In the forensic investigation of the crime of trafficking and illicit drug use, the research activity is carried out with great difficulties, because one of the forms of crime with the highest rate of the dark number of crime and almost impossible to estimate is the illicit trafficking and consumption of drugs, as victims are most often accomplice in this form of crime, and establishing the diversity of substances that fall into the narcotic sphere is relative.
\end{abstract}

KEYWORDS: forensic research, drugs, psychoactive substances, drug trafficking, illicit drug use.

\section{INTRODUCTION:}

Illicit drug trafficking and consumption is a form of criminality that is in the attention of both national and international organisation and which must be effectively addressed and combated by all countries whose persons are involved as perpetrators or victims of drug trafficking crime. The scale of the current problem of narcotics goes beyond the control power, constituting a threat both for the health and safety of the people and for the economic and social order of the world. The main cause of drug trafficking and illicit drug trafficking is the tendency of criminals to obtain significant illegal income, criminal activity being one of the most profitable, being ranked, according to income, second in the world, after the trafficking of weapons.

\section{GENERAL CONSIDERATIONS:}




\section{Petronela-Diana Ferariu, Valentina Avrămescu}

Drugs are narcotic or psychotropic plants and substances, or mixtures that they contain, their definition in Romania being given by Law no. 143 of 26 July 2000 on combating trafficking and illicit drug use. According to the World Health Organization, the drug is the substance that is absorbed by a living organism, modifying one or more functions of it. In the pharmacological sense, the drug is a substance used in medicine, the abusive use of which can create physical or mental dependence, or serious disorders of mental activity, perception and behavior. Adoption of Law no. 143 of 26 July 2000 represented a qualitative leap from the previous regulations, changing both the conceptions and the strategies to fight against what was called the " the scourge of the contemporary world". The need to harmonize national and international legislation required the elaboration of Law no. 143 of 26 July 2000 which establishes the categories of drugs under control, the facts that constitute drug trafficking, but also contains procedural dispositions applicable in the field of discovery and investigation of this type of crime. The categorizing of psychotropic products or substances is important for the legal classification of the offence. The number of psychotropic substances on the list of those under control has increased steadily (Sabău G. V., 2007, 224). This aspect highlights the concern of traffickers for research, identification and use of new substances

such as drugs, but also the interest of the authorities in keeping the trafficking and illicit drug use under control. The criminals involved are constantly improving their methods of action, always being one step ahead of the authorities. They adapt quickly and flexibly to the new geostrategic, legislative, economic and technological evolution conditions, by using the entrepreneurial structures and by combining the illegal business activities with the legal commercial ones (Niţă N., 2001, 78).

The International Narcotics Control Strategy Report (INCSR) shows that Romania is not a major source of drugs, but has the role of a transit country for narcotics. In order to carry out the terrestrial transport, the traffickers resort to both vehicles destined for freight transport and those for passengers. Also, as element of novelty, there was an evolution in the Romanian market of drugs and synthetic psychotropic substances, called designer drugs or spice (Buzatu N. E., 2016, 10).

According to the European report on the nature of drugs, heroin that arrives in Romania is intended for consumption for the internal market and for transit to Western Europe. This drug enters the territory of the country with the help of international transport companies of persons and freights or through the use of vehicles registered in Romania and driven by Romanian citizens, after which it is dispatched further by similar means (Stanciu V., 2002. 101). The most common destinations are the Netherlands, Germany and the United Kingdom. Cocaine is still an expensive drug for the intern market of Romania, which is also why it is brought in small quantities from Western Europe or South American countries. At the same time, the traffickers of this category of drugs turned their attention to the port of Constanta as an entry point into Europe and bypass the classic routes where the control is carried out more carefully, the evidence being, the significant catches from this port. Cannabis remains the most commonly used drug in Romania, the intern market being supplied from both European producing countries (Moldova, Holland, Belgium, etc.) and from intern production (with an increase in the number of indoor cultures throughout the country). The hashish is brought to Romania in the most part from Spain, through regular courses (by carriages or packages) or by air, especially the low cost ones. 
METHODOLOGIC DIRECTIONS IN CRIMINALISTIC RESEARCH FOR THE OFFENCE OF TRAFFICKING AND ILLICIT DRUG CONSUMPTION

INVESTIGATION: The investigation of the crime of trafficking and illicit drug use is carried out with great difficulties, the criminals permanently improving their methods of action, because the huge profit they obtain mobilizes them to intensify the research in discovering other derivatives and new methods of trafficking. The production of drugs is bought and distributed throughout the world by the so-called "traffickers" (Rădulescu S., 1999, 164). They are the main beneficiaries of the drug trade and are the hardest to capture. In Romania, and not only, there are so-called "area dealers", then on smaller areas there are "local dealers", followed by "sellers" and finally "street distributors", who are also most exposed to be captured. Many of the street distributors are consumers themselves and carry out this activity in exchange for the daily dose (Buzatu N. E., 2016, 121). The structure of a drug trafficking network is of the organizational pyramid type and the capture of the street distributors does not solve the problem of illicit drug trafficking and consumption, them being at the base of the pyramid. Moreover, the legislation provided to halve the limits of penalties for people who, during the criminal prosecution, denounce or facilitate the identification and criminal prosecution of other perpetrators involved in operations with narcotic substances. Thus, the capture of the street distributors does not solve the problem of illicit drug trafficking and consumption because they, in order to benefit from the reduction of the penalty, denounce other street consumers or distributors and not higher hierarchical persons from the pyramid level, thus not reaching the capture of the area dealers, local dealers, sellers or traffickers. In the conditions in which the way of committing traffic offenses and illicit drug use presents increasingly distinct forms, it was necessary to introduce in the Romanian legislation new modalities of forensic investigation, meant to increase the possibilities of the judicial bodies in discovering, combating this phenomenon (Sabău G. V., 2007, 274). Therefore, Law no. 143 of 26 July 2000 on the prevention and control of trafficking and illicit drug provides special investigative methods and techniques, such as supervised delivery, use of undercover investigators and collaborators, the surveillance of telecommunications systems (Buzatu N. E., 2016, 186).

Supervised delivery: In recent years, international interest has been observed in the cooperation of different states in the fight against drugs, whose main objective is to detect and combat the illicit activities of drug traffickers. In article $1(\mathrm{k})$ of the Convention against the illicit trafficking of narcotics and psychotropic substances, of December 20, 1988, it is shown that the expression supervised delivery indicates the methods by which drugs, substituted substance or psychotropic substances may be passed through the territory of one or more countries, with the consent and under the control of the competent authorities of the indicated countries, in order to establish the identity of the persons involved in the crime. The supervised delivery method is the cooperation of the states for the detection and arrest of drug traffickers, who carry out their criminal activity entirely or partially within the territory of these states. The main objective of the supervised deliveries is the discovery of the entire drug trafficking network, from the cultivator, producer, trafficker to dealers, buyers and consumers (Stancu E., 2007. 113). The supervised deliveries can also be of two types, respectively the supervised delivery with the substitution of drugs, which in turn can be with total or partial substitution of the substances and the supervised delivery without the substitution of the drugs (Dima T., 2000, 75). The method of delivery is chosen according to the particularities of each case. When there is data, information or suspicion that a substance is being exported, imported or in transit through the territory of a country for the purpose of the manufacture of 


\section{Petronela-Diana Ferariu, Valentina Avrămescu}

psychotropic substances or drugs, each signatory State must inform the competent authorities as soon as possible and make the information available to the authorities regarding the name and address of the exporter, respectively of the importer, the indication of the substance, the quantity of substance exported, the point of entry and exit from the country, the date of dispatch, the payment methods used and all other essential elements. When organizing supervised deliveries, it is important that immediately after the information and data have been communicated to the countries in which the drugs will be transited, to obtain the approvals from the authorized institution. The organization of supervised deliveries cannot be authorized by using this method of investigation if the national security, public order or public health would be endangered. The operation of the supervised delivery is considered to be performed when the substances reach the consignee, and the objectives proposed in terms of tactical-informative and judicial-operative aspect have been reached (Buzatu N. E., 2016, 196).

The undercover investigator and collaborator: From the category of new methods successfully practiced in the fight against illicit drug trafficking by the judicial bodies and the competent authorities of our country, there is the infiltration of investigators and undercover collaborators in the groups of criminals. This method is particularly useful in criminal cases, where there is little evidence and no persons are willing to testify. The infiltration operations of investigators and collaborators can be short or long term and can take various forms. These can be operations of pseudo-purchase, flash-roll, pseudo-sale and penetration of networks or groups. The pseudo-purchase is materialized by presenting to a person as a potential buyer the product or object of the crime. The flash-roll consists of exposing the amounts of money to potential sellers of prohibited goods or of illicit origin in order to simulate the intention to buy. The pseudo-sale consists in the plan in which the agent tends to sell substances that are the product or object of an offense. Infiltration of the undercover investigator and collaborator in the criminal groups can be done when information about the intentions and ways by which the crimes are committed cannot be obtained, in case no evidence can be obtained regarding the activity of the criminal group and in the situation that using this method would reduce the expenses incurred during the research (Buzatu N. E., 2016, 193). In the making of the request of the authorization addressed to the prosecutor, the data referring to the facts and persons against which there is a suspicion that he is dealing with illicit drug trafficking, as well as the period for which authorization is requested will be mentioned. Regarding the duration for which this authorization can be issued, Law no. 143 of 26 July 2000, specifies that the authorization period is "no more than 60 days and can be extended for duly justified reasons, each extension may not exceed 30 days". The real identity of the undercover investigator and collaborator cannot be disclosed during or after the completion of the action. Their identity can be known by the competent prosecutor to authorize the use of the undercover investigator, while respecting professional secrecy. After obtaining the authorization, the undercover investigator or collaborator may procure the psychotropic drugs or substances registered in the authorization issued by the prosecutor only in the express quantity mentioned. Any other activity that the undercover investigator or collaborator carries out other than the one provided in the authorization issued by the prosecutor is in the falling within the illegal activities (Buzatu N. E., 2012, 101). It is indicated that the infiltrated policeman does not participate in other activities that could be a criminal offense. In the situation in which undercover investigator or collaboratorit is coerced and there is a risk of committing any 


\section{METHODOLOGIC DIRECTIONS IN CRIMINALISTIC RESEARCH FOR THE OFFENCE OF TRAFFICKING AND ILLICIT DRUG CONSUMPTION}

action that constitutes a criminal act, must be informed immediately the policeman of the situation, to cease the whole activity.

Audio or video intercepts and recordings: Like any other way of proof, the audio and video interceptions and recordings aim to identify the truth in question, with the purpose of proving the circumstances that preceded, accompanied or succeeded the offense, the participants in the illegal activity, the degree of participation, the substances that committed the object of the criminal activity, the means used to implement the crime, etcetera (Stancu E., 2007. 184). The authorization for the interception and the registration is issued for a maximum of 30 days, with the possibility of extension in the same conditions for duly justified reasons, each extension not exceeding 30 days. The total duration of authorized interceptions and records, regarding the same person and the same act, may not exceed 120 days. In order to carry out the activity of intercepting and recording audio or video, logistic support from the specialists in the field is required. They have the obligation to maintain professional secrecy regarding the operations performed. In urgent situations, when the delay in obtaining the authorization would damage the criminal activity, the prosecutor supervising the criminal investigation may decide, on a provisional basis, by a motivated ordinance, to intercept and record on the magnetic tape or on any other media the calls or communications, for a maximum of 48 hours. The prosecutor has the obligation within 48 hours to submit to the court the order along with the technical system on which the intercepts and records are made as well as a report in which the essential of the intercepted conversations is transcribed. The judge must rule within a maximum of 24 hours on the legality and well founded of the ordinance issued by the prosecutor and in the case in which he confirms it and it is necessary, the further authorization of the interception and registration will be ordered. If the interception and registration were done in a language other than Romanian, the calls will be translated and their transcription will be made in the Romanian language (Stancu E., 2007. 174). The translation must be certified by an authorized translator. The magnetic tape or any other device on which the recording of the call was made, its transcript and the written report is presented to the court. After hearing the prosecutor and the parties, the court decides which of the obtained data is of interest in investigating and resolving the case. The provisions of the special laws in the field of combating organized crime expressly indicate, as evidence, access to telecommunications or information systems, establishing the authorization mode and conditions. The research method by using video recordings represents a superior technical way of judicially fixing the operative moments of the criminal activity. The videomagnetic tape ensures an overall and continuous recording, so that it can be considered as having a higher degree of objectivity and accuracy compared to other recording techniques (Stancu E., 2007. 213). In order to prove the authenticity of the audio recordings, two tactical and methodological rules must be observed, respectively to present the original audio recording and the technical recording system that was used at the time of the interception.

\section{CONCLUSIONS}

At the nationwide, taking into account the unfortunate consequences of drug trafficking and illicit drug use, it is necessary to intensify the study of the forensic investigation of the drug problem, in order to identify the most effective ways of combating this scourge, so that it can be reached up to the top of the pyramid, in each case subjected to criminal investigation, which would allow the networks of traffickers to be annihilated and not just to take action 
against small distributors, street dealers and consumers. At the international level, the difficulties of cooperation in the fight against drug trafficking are also due to the fact that there is still no legal uniformity in classifying substances as narcotic, although at the international level numerous conventions have been adopted in this area, precisely for this purpose.

\section{BIBLIOGRAPHY}

Boroi, Alexandru. Neagu, Norel. Sultănescu, Radu. 2001. Infracţiuni prevăzute de Legea $n r$. 143/2000 privind combaterea traficului şi consumului ilicit de droguri.. București: Editura. Dima, Traian. 2000. Traficul și consumul ilicit de stupefiante. București: Editura Lumina Lex. Hotca, Adrian, Mihai. Dobrinoiu, Maxim. 2008. Infracțiuni prevăzute în legi speciale. Comentarii și explicații, vol. I. București: Editura C.H. Beck.

Legea nr. 143 din 26 iulie 2000 privind combaterea traficului și consumului ilicit de droguri. Textul actului publicat în Monitorul Oficial nr. 362/3 aug 2000.

Buzatu, Nicoleta-Elena. 2015. Fenomenul consumului de substanțe noi cu proprietăți psihoactive (Etnobotanice). București: Editura Universul Juridic.

Buzatu, Nicoleta-Elena. 2012. Traficul și consumul ilicit de droguri. București: Editura Universul Juridic.

Niță, Nelu. 2001. Dimensiunile consumului ilicit de droguri în România comparativ cu statele Uniunii Europene. București: Editura Viaţă şi Sănătate.

Rădulescu, Sorin. 1999. Devianţă, criminalitate şi patologie socială. București: Editura Lumina Lex,

Stanciu, Viziteu. 2002. Combaterea traficului ilicit şi a contrabandei vamale cu droguri de către autoritatea vamală. București: Editura Ministerului de Interne.

Stancu, Emilian. 2007. Tratat de Criminalistică. București: Universul Juridic.

Sabău, Georgeta Valeria. 2007. Traficul și consumul ilicit de droguri şi precursori. București: Editura Universul Juridic. 